Prace Filologiczne. Literaturoznawstwo 11(14) 2021

ISSN 2084-6045

e-ISSN 2658-2503

Creative Commons: Uznanie autorstwa 3.0 PL (CC BY)

DOI: $10.32798 /$ pflit.595

\title{
W POPRZEK GATUNKÓW. O POTRZEBIE NOWEJ TAKSONOMII GENOLOGICZNEJ DRAMATU
}

\author{
Across the Genres. On the Need for Alternative 'Literary Genetics' of Drama
}

\author{
MARTA KARASIŃSKA \\ Uniwersytet im. Adama Mickiewicza w Poznaniu, Polska \\ E-mail: martakar@amu.edu.pl \\ https://orcid.org/0000-0002-7348-9084
}

\begin{abstract}
The subject of the relevance of genre typology and consequently the functional role of periods in the historical and literary process as well as the time marks as closely related to the process of periodisation pose the key issue for the discussion on contemporary literature. It turns out that drama is the literary genre that is specifically prone to gradual genre erosion. This disintegration of its genological forms becomes particularly apparent at the turn of the $20^{\text {th }}$ century due to the devaluation of the fundamental categories of the genre such as dialogues, characters or the plot. Later, in the 1950s it transforms into 'anti-drama' represented by the theatre of absurd only to develop into a formula of a 'postdrama' in the 1970s. Its poetics is determined by composition techniques including dominance of a moving image, heterogeneity of artistic style, non-literariness, and distortion that take their origin from various systems. Postdrama reveals itself as an intermedia, transmedia and transsystem category that goes beyond the literary genre, positioning itself somewhere at the interface between the language text, television genres, visual arts, and digital media.
\end{abstract}

Keywords: literary genre, drama, postdramatic, intermedia, transmedia, transsystem, digital media

\section{Streszczenie}

Kluczową kwestię dla rozważań o literaturze najnowszej stanowi problem aktualności typologii gatunkowej, a zatem także funkcjonalnego wymiaru periodyzacji procesu historycznoliterackiego i związanej z nim cezury. Rodzajem literackim szczególnie podatnym na erozję gatunków okazuje się dramat. Rozpad jego form genologicznych zapoczątkowany na przełomie XIX i XX w. (za sprawą dewaluacji podstawowych, rodzajowych kategorii: dialogu, postaci i fabuły), 
w latach pięćdziesiątych XX w. wiedzie przez „,antydramat” absurdystów ku zrodzonej w latach siedemdziesiątych formule „postdramatu”. Wyznacznikami poetyki „postdramatycznej” okazują się pochodzące z różnych systemów chwyty kompozycyjne, m.in. dominacja ruchomego obrazu, heterogeniczność stylu artystycznego, aliterackość, deformacja. Postdramat staje się kategorią intermedialną, transmedialną i transsystemową, wykraczającą poza genre pisma, sytuującą się na pograniczu tekstu językowego, gatunków telewizyjnych, sztuk wizualnych i mediów cyfrowych.

Słowa kluczowe: rodzaj literacki, dramat, postdramatyczny, intermedialność, transmedialność, transsystemowość, media cyfrowe

Sformułowane przez redaktorów tomu problemy związane z podstawową dla opisu procesów historycznoliterackich kategorią cezury wytyczają szeroki zakres rozważań, stawiając pytania o ciaggą aktualność tradycyjnych metod systematyzowania dziejów literatury. Zadekretowana w przeszłości jako wymagany wyznacznik ścisłej periodyzacji, wydzielała precyzyjnie estetyki w zgodzie z obowiązującymi poetykami, paradygmatami humanistycznymi i ramami wydarzeń historycznych. Wyszczególniała charakterystyczne dla okresu prądy, konwencje i - co najistotniejsze - typowe dla nich gatunki. Im bliższe współczesności jednak, tym bardziej przecież kapryśne, niepodległe wobec genologicznych zaszeregowań. Gatunek, jako podstawowa jednostka taksonomiczna procesu historycznoliterackiego, sprawia bowiem oczywisty kłopot. Czy jest nadal definiowalnym, podlegającym weryfikacji, zamkniętym elementem systemu, konstytuowanym przez nieredukowalny zespół cech dystynktywnych (wyznaczników gatunkowych)? Dominium obligatoryjnej powtarzalności, ergo stanowionej konwencjonalizacji spełnianej idealnie w zamierzchłej idei normatywizmu? Wiązką rozpoznawanych chwytów otwierającą się na wariacyjne transformacje? A jeśli tak, to $\mathrm{z}$ jakim zakresem poliwalentności umożliwiającym identyfikację w ramach wskazanego genre? A może - na koniec - samostanowiącą się, jednorazową manifestacją stawiającą znak równości między tekstem i gatunkiem? Unieważniającą dystynkcję tożsame-nietożsame, likwidującą kategorię gatunkowej konstanty, odmiany, genologicznego inwariantu? Gdzie zatem przebiegają międzygatunkowe cezury - wydzielają zbiory tekstów czy jednostkowe, potencjalnie architekstualne ich artykulacje?

Druga połowa lat dziewięćdziesiątych XX w. przynosi ze sobą kolejną falę namysłu nad zagadnieniem gatunków stawiającą w centrum zainteresowania kwestię ich redefinicji czy może już w ogóle podważającą zasadność wyodrębniania podlegających przemianom form genologicznych. Toczący się o kryzys gatunku spór unieważnia Stanisław Balbus ${ }^{1}$ prowokacyjną tezą o wyłącznym kryzysie teorii, nieskutecznej w obliczu nowych zjawisk formatotwórczych,

\footnotetext{
${ }^{1}$ S. Balbus, „Zagłada gatunków”, „Teksty Drugie” 1999, nr 6.
} 
wykluczajac jednak z pola widzenia zjawiska intermedialnych filiacji tekstu i zamykając gatunek literacki wyłącznie w obszarze słowa. Upowszechniające się w ostatnich latach z coraz większym nasileniem zabiegi sytuowania tekstów na granicy sztuk i mediów (szczególnie częste w przypadku dramatu) znacznie jednak komplikują nawet „liberalne” operacje taksonomiczne, nierzadko podajac w wątpliwość ich artystyczny charakter. W jakie porządki typologiczne zatem wpisać zaprzeczające tekstowej koherencji hybrydy, przekraczające niekiedy granice sztuki i niesztuki? Jak wyodrębnić rudymentarną dla stanowienia gatunku kategorię różnicy? Pozostający w dwugłosie z Balbusem Edward Balcerzan, w opublikowanym w tym samym numerze ,Tekstów” artykule $W$ stronę genologii multimedialnej ${ }^{2}$, w sposób bliski autorowi „Zagłady gatunków” stwierdza:

Skoro gatunkiem jest skład zasad organizacji tekstu, zatem należałoby postawić znak równości między morfologią a gatunkiem, co oznacza identyczność „bycia tekstem” i „bycia w gatunku". W perspektywie teoretycznej nie ma mowy o utworach pozagatunkowych, traca sens pojęcia „gatunków mieszanych”, hybrydalnych itp. - wszystkie są jednym i tym samym: kombinacjami chwytów³ .

Balcerzan dostrzega jednak pewną nieoczywistość sytuacji w przypadku tekstów o nie literackiej (i nie językowej) wyłącznie proweniencji. W przypadku „zróżnicowanych przebiegów komunikacyjnych” proponuje mówić już nie o gatunkach, niedefiniowanych przecież w wielu obszarach sztuki i praktyk społecznych, lecz quasi-rodzajowych paradygmatach: „Paradygmat oznacza zarówno współdziałanie cech, jak i dynamiczne kolizje wewnętrzne, nieodzowne napięcia między sprzecznościami"4.

Czy zatem unifikująca przestrzenią teorii różnorodnych przebiegów komunikacyjnych, włączających literaturę, mogłaby stać się genologia ogólna, nadal na przecięciu mediów określająca quasi-rodzajową tożsamość paradygmatów kulturowych?

Dokonująca aktu przekroczenia refleksja Balcerzana zmierza już od genologii wyłącznie literackiej ku multimedialnej:

Genologia multimedialna byłaby wiedzą o normach „gry znaków”, „gry form” słownych, wizualnych, dźwiękowych, które pojawiają się w dowcipach, reklamach, kampaniach wyborczych, nie są też obce literaturze, manifestom z „przymrużeniem oka” (Juliana Tuwima Pegaz dęba, Stanisława Barańczaka Pegaz zdębiat), utworom satyrycznym, parodystycznym, rozgałęzieniom - spokrewnionego z felietonem - kabaretu (więc i poezji kabaretowej), centonom, kolażom, „wiązankom” melodii, „kłączom” postmodernistycznym, „,hipertekstom”, aż do sztuki autotematycznej, która oscyluje między intencją eseistyczną a felietonową ${ }^{5}$.

\footnotetext{
${ }^{2}$ E. Balcerzan, $W$ stronę genologii multimedialnej, „Teksty Drugie” 1999, nr 6.

${ }^{3}$ Ibidem, s. 12.

${ }^{4}$ Ibidem, s. 21.

${ }^{5}$ Ibidem, s. 23.
} 
W zgodzie z własnym rozróżnieniem genologii literackiej i multimedialnej Balcerzan proponuje łączący je, rozpięty między porządkiem metonimicznym i metaforycznym, gatunkowy dwuszereg:

Szereg monomedialny tworzą gatunki wykorzystujące możliwości jednego urządzenia komunikacyjnego, które - zgodnie z omówionymi już kryteriami - może być technicznie jednorodne (pismo) lub łączące rozmaite techniki (opera). W żadnym szeregu monomedialnym gatunki się nie dublują; tworzą natomiast serię metonimiczną, czyli pozostają względem siebie w stosunku - mniej lub bardziej odległej - styczności. [...]

W szeregach polimedialnych - odwrotnie - nie ma gatunków dalekich i bliskich, łączy je bowiem - oraz różnicuje - stopień podobieństwa. Wszelkie układy polimedialne w świecie gatunków są związkami metaforycznymi: tutaj jeden gatunek (np. film fabularny) może być mniej lub bardziej wiarygodną metaforą innego gatunku (np. powieści) ${ }^{6}$.

Tendencje rozwojowe w sztuce najnowszej prowokują do ukonstytuowania kolejnych, następujących po proponowanej przez Balcerzana genologii multimedialnej, teorii gatunku - inter- i transmedialnej:

- genologia multimedialna obejmuje formy zderzające odmienne systemy komunikacyjne, ,partnerskie”, innorodne media, zachowujące swą niezależność i zarządzające nimi poetyki,

- genologia intermedialna sytuuje teksty w środowisku interferujących między sobą mediów, decydując o częściowym osłabieniu ich autonomii (często podporządkowując jedno drugiemu) i ujawnianym anektowaniu w korpus gatunku elementów zapożyczanych z obcego zbioru chwytów,

- genologia transmedialna włącza zjawiska przekraczające granice mediów, likwidujące ich niezależność i scalające różnorodne języki w nową estetyczną całość.

Postępująca już od przełomu XIX i XX w. stopniową erozję, czy - w latach ostatnich - wręcz niekiedy celową dewastację tradycyjnych form literackich, wymuszającą współcześnie dezaktualizację utrwalonych reguł ich kwalifikowania i wyodrębniania (zatem stosowania cezur), najcelniej ilustrują dzieje gatunków scenicznych i zmieniające się w czasie narzędzia ich opisu. Powodem tej sytuacji są dwojakie uwikłania artystyczne dramatu, zależne z jednej strony od zmiennych historycznie estetyk literackich, z drugiej od narzucanego mu dyktatu gwałtownie przeobrażających się poetyk i technik teatralnych (a szerzej widowiskowych i medialnych) ${ }^{7}$.

\footnotetext{
${ }^{6}$ Ibidem, s. $16-17$.

${ }^{7}$ Szczególną podatność dramatu na rozpad genologicznej typologii, w związku z napierającymi na niego $\mathrm{z}$ wielką siłą dyskursami nieliterackimi i multimediami, prowadzącymi w ostateczności do rezygnacji z definicji tekstu dramatycznego jako kategorii umocowanej w słowie, zwracała uwage Seweryna Wysłouch. Eadem, Nowa genologia - rewizje i interpretacje, w: Polska genologia. Gatunek w literaturze wspótczesnej, red. R. Cudak, Warszawa 2009.
} 
Rozwój dramatu europejskiego zadekretowany zgodnie z utrwaloną, wielowiekową tradycją na mocy Poetyki Arystotelesa ${ }^{8}$, szczególnie „restrykcyjny” wobec trzeciego rodzaju, podzielonego na wyraźnie definiowane gatunki (posadowione głównie na dystynkcji komedia-tragedia) aż do końca XIX w. budował klarowne cezury międzygatunkowe, co najwyżej sytuując na ich przecięciu (bądź w obszarze międzyrodzajowym) nowe, znów precyzyjnie definiowane formy (melodramat, dramat romantyczny), dla których stałym punktem odniesienia były jednak i tak klasyczne rozróżnienia, ergo cezury, Stagiryty. Precyzyjne jakości kompozycyjne (trzy jedności, postać protagonisty, coup de théâtre, konstrukcja fabuły $\mathrm{z}$ intrygą i kulminacją, replika, didaskalia etc.) jako dyrektywy formalne „dyscyplinowały” trzeci rodzaj przez znaczną część jego historii.

Przełom XIX i XX w. przynosi ze sobą klarownie jeszcze w perspektywie tradycyjnej, akademickiej historii literatury definiowane, także obok klasycznych, nowe gatunki: dramat naturalistyczny, symboliczny, ekspresjonistyczny, które jednak z perspektywy lat siedemdziesiątych XX w. objawiły już swą nieoczywistość. W przedziale „długiego czasu trwania” trzeciego rodzaju przyjęta na użytek dydaktyki szkolnej i akademickiej periodyzacja mniej zatem waży, ukazując niewystarczalność wyodrębniających autonomiczne estetyki kryteriów stosowanych wobec dramaturgii okresu Młodej Polski, dwudziestolecia, literatury po 1945 r. i literatury najnowszej. Dzieje nowoczesnego i ponowoczesnego dramatu to już nie tylko historia autorów czy prądów, a zatem i gatunków, ale przebiegającego konsekwentnie przeobrażania rodzajowej „gramatyki” literackiej. Symbol, realizm, tragizm, komizm przestają pełnić funkcję kategorii estetycznych i poetologicznych generujących formy genologiczne. Zachodzące procesy literackie prowadzą wszak do rozpadu głębokich struktur tekstu uniwersalnych dla wszystkich gatunków scenicznych. Z początkiem XX w., wraz z przekroczeniem progu nowoczesności, dochodzi bowiem do powolnego „rozmiękczania” form dramatycznych, polegającego na stopniowym destruowaniu klasycznych wyznaczników rodzajowych, obligatoryjnych dla dramatu dominant kompozycyjnych - postaci, dialogu i fabuły, spełniających dotychczasowe wymogi narzucane przez akcję sceniczną.

Rozwijające się w czasie zjawisko diagnozują znane książki: Teoria nowoczesnego dramatu 1890-1950 Petera Szondiego', Teatr absurdu Martina Esslina ${ }^{10}$ i Teatr postdramatyczny Hansa-Thiesa Lehmanna ${ }^{11}$. Te popularne, klasyczne

${ }^{8}$ Bertolt Brecht, protestując przeciwko skostniałej estetyce dramatu mieszczańskiego, utożsamia go wprost z modelem poetyki Arystotelesowskiej.

${ }^{9}$ P. Szondi, Teoria nowoczesnego dramatu 1890-1950, thum. E. Misiołek, Warszawa 1976.

${ }^{10}$ M. Esslin, The Theatre of the Absurd, Garden City 1961.

${ }^{11}$ H.-T. Lehmann, Teatr postdramatyczny, tłum. D. Sajewska, M. Sugiera, Kraków 2004. 
dla refleksji teatrologicznej opracowania, czytane oddzielnie, wydzielają trzy autonomiczne okresy w rozwoju dramatu, z których każdy wprowadza kolejny, właściwy dla siebie etap dekompozycji rodzaju oraz dekretowaną przezeń literacką estetykę i konkretnych gatunków, i generowanych przez nie tekstowych, jednostkowych już artykulacji: koniec XIX i pierwsza połowa XX w., lata pięćdziesiąte i sześćdziesiąte $\mathrm{XX}$ w. oraz rozpoczynające się w latach siedemdziesiątych wejście w okres postdramaturgii, stanowiącej najbardziej spektakularną formułe „zagłady gatunków”, negującą nawet - w związku z transmedialnym charakterem dramatu - podstawową dla poetyki cezurę oddzielającą literaturę nie tylko od zjawisk nieliterackich, ale także od form niejęzykowych i nieartystycznych. Ów synchroniczny, wewnętrzny ład wyznaczonych epok poddany jednak nałożonemu nań ponadgatunkowemu, zmieniającemu się w czasie, przebiegającemu swobodnie od okresu do okresu porządkowi przekształcanych, wyabstrahowanych cech strukturalnych dramatyczności jako nieredukowalnych, elementarnych kategorii kompozycyjnych całego rodzaju, niezależnych od determinant konstrukcyjnych poszczególnych gatunków, pozwala już na inny ogląd zjawisk, osadzonych nie w określonych periodach, nie w wyodrębnionych formach genologicznych, lecz w ciągłym przechodzeniu od konwencji do konwencji. Pokazuje nie historie izolowanych gatunków, lecz przeobrażenia wspólnych dla nich wszystkich literackich „stałych” kompozycyjnych (głównie postaci, dialogu, fabuły), podlegających tym samym procesom, niezależnym od wyznaczników poetyki poszczególnych genres. Czytane z tej perspektywy, stanowiące dla siebie wzajemne konteksty książki Szondiego, Esslina i Lehmanna, nakładające na dotychczas niezależne ich odczytania nowy porządek ,poprzecznej" teraz lektury, opisują najważniejsze, następujące po sobie systematycznie kolejne etapy dekompozycji rodzaju, przebiegające swobodnie ponad granicami wyodrębnionych przez badaczy okresów. Hans-Thies Lehmann w swych rozważaniach akcentuje ciągłość zapoczątkowanego na przełomie XIX i XX w. procesu transformacji gatunków scenicznych, choć zmieniających się w czasie, to do lat siedemdziesiątych zawsze jednak zachowujących ,istotę teatru dramatycznego" i przedstawiających ,językowe światy”. Ten ewolucyjny przebieg przemian artystycznych umocowanego nadal w słowie dramatu w latach siedemdziesiątych został radykalnie przerwany przez inwazję wszechobecnych mediów konstytuujących całkowicie inną już estetykę teatru postdramatycznego, niemożliwą jednak bez antycypujących ją zjawisk dekonstruowania literackiej poetyki tekstów, odnajdywanych przez Lehmanna m.in. w Landscape Play Gertrude Stein, tekstach Antonina Artauda pisanych dla Teatru Okrucieństwa i w Teatrze Czystej Formy Witkacego ${ }^{12}$.

\footnotetext{
${ }^{12}$ Ibidem, s. 65.
} 
Pierwszy etap dewastacji form dramatycznych to nade wszystko postępująca w czasie ich epizacja i będąca jej wynikiem dewaluacja scenicznego dialogu, w coraz większym stopniu odzieranego ze swojej sprawczej roli. Mimo zachowania jeszcze zewnętrznego rygoru naprzemiennych replik scenicznych słowo traci swą fabułotwórczą moc, przemieszczając się z pozycji kreatora zdarzeń ku formule konwersacyjności (sztuki Thomasa Williama Robertsona, Antoniego Czechowa), narracyjnego komentarza (Gerhart Hauptmann, Bertolt Brecht), ekspresji psychicznego interioru (Maurice Maeterlinck, twórczość ekspresjonistów). Poddawany epizacji i liryzacji tekst dramatyczny, posadowiony teraz na granicy rodzajów literackich, dewaluuje zatem konsekwentnie następną kategorię genologiczną, jaką jest klarownie komponowana, dynamiczna, sceniczna fabuła składająca się z kolejnych, przeplatających się przyczyn i skutków, proponując formę dramatu statycznego (Maeterlinck), stacyjnego (ekspresjonizm), analitycznego (Ibsen), epickiego (Brecht). Okres 1880-1950 rozpoczyna tym samym dokonującą się do dziś korozję modelu dramatu Arystotelesowskiego, pozostawiając jeszcze wprawdzie jako podmiot akcji scenicznego bohatera (już nie zawsze w pełni indywidualizowanego), z mocno jednak ograniczoną potencją fabularną.

Pojawienie się w latach pięćdziesiątych, zdefiniowanego przez Martina Esslina, teatru absurdu wydawało się ostatecznym zwieńczeniem ewolucji form dramatu, degradującego mówiące indywiduum i poddające je uwolnionemu żywiołowi, ujętego wprawdzie jeszcze w strukturę dialogu, jednak niezależnego od postaci języka. Opozycja dramat-antydramat jednoznacznie wskazywała na dokonane w twórczości absurdystów całkowite zaprzeczenie wielowiekowej tradycji trzeciego rodzaju, nie pozostawiając już w założeniu miejsca na kolejne formuły gatunkowe.

Lata siedemdziesiąte, wraz z ekspansją nowych mediów i technik widowiskowych, rozszerzyły jednak tę, zamykającą z pozoru historię rodzaju, dychotomię do triady dramat-antydramat-postdramat, proponując teraz całkowicie nową jakość estetyczną, niekorespondującą już nawet przez negację z rodzajem Arystotelesowskim.

Literatura sceniczna (czy zawsze literatura?) powstająca „po dramacie” unieważnia rodzajowe konstanty genologiczne, ostatecznie dewastuje gatunki, pojmowaną jako aktanta postać, generowaną przezeń fabułę i dialog. Problem postępującej stopniowo we współczesnej dramaturgii destrukcji postaci, fabuły i dialogu podejmują autorzy Stownika dramatu nowoczesnego i najnowszego wydanego pod redakcją Jean-Pierre'a Sarrazaca. Śmierć bohatera ${ }^{13}$ jako sprawczego

${ }^{13}$ Elinor Fuchs, w tekście pochodzącym z 1983 r., początki opisywanego w słowniku Sarrazaca, odnajdywanego u progu modernizmu, procesu rozpadu bohatera scenicznego wskazuje już znacznie wcześniej, bo w okresie przełomu romantycznego, charakteryzującego się - paradoksalnie - 
podmiotu konstruującego dialogi i zdarzenia manifestować się może z różnym natężeniem poprzez eliminację jego kolejnych, tradycyjnych cech strukturalnych. Wśród szczególnie istotnych jej przejawów autorzy wymieniają utratę cech fizycznych postaci, jej zakorzenienia w kontekście społecznym i indywidualizującego ją imienia. Niekiedy zjawiska te pogłębione zostają poprzez jej rozbicie na kilka niezależnych bytów (niejednokrotnie osadzonych w różnych formacjach czasowych) czy skłonność do multiplikacji. Jak podkreślają badacze, prowadzą one w konsekwencji do kryzysu tożsamości postaci, która „utraciła wewnętrzną substancję i została skazana na błądzenie w poszukiwaniu ucieleśnienia i wprzęgnięcia w kierat określonej fabuły”, której logika „stanowi funkcję spójności postaci, podporządkowanych organicznej akcji”"14. Szczątkowa postać uzyskuje dyspozycję kreowania ledwie szczątkowej fabuły i artykułowania rozpadającego się dialogu, pomieszczonego w pęknięciu między pozbawionym znamienia indywidualności podmiotem wypowiedzi i wypowiadanym dyskursem. Diagnozowane w słownika Sarrazaca „trzy kryzysy” strukturalnych filarów tekstu dramatycznego z wejściem w wiek XXI nabrały dodatkowego impetu, w skrajnych przypadkach prowadząc do całkowitej likwidacji postaci i zatomizowanej choćby fabuły zastępowanych teraz w pełni już uwolnionym dyskursem.

Inflacja podlegających definicji form dramatu zależy jednak zarówno od ogólnego zjawiska demontażu systemu gatunków literackich, jak i od gwałtownej zmiany estetyki teatralnej, teraz marginalizującej słowo i otwierającej się na - generowany głównie cyfrowo - obraz. Dobrochna Ratajczakowa, zwracając uwagę na dokonany już rozwód dramatu jeszcze literackiego z tekstami podporządkowanymi nadrzędnemu przymusowi nowej sceniczności, formułuje celnie pojęcie rodzajowego simulacrum, w ,jakimś tylko stopniu należącego do literatury", obejmującego scenariusze teatralne, paradramaty, quasi-sztuki, podobniki, strumienie dramatyczne, analogony formy dramatycznej ${ }^{15}$. Wszystkie one znakomicie się mieszczą w wypierającym tradycyjny teatr dramatyczny paradygmacie postdramatyczności. W poświęconych mu analizach Hans-Thies Lehmann wskazuje kilka właściwych dla niego kategorii strukturalnych. Tworzą one konstelację elementów składających się na uniwersalny model kompozycyjny.

przejściem od dominacji dramaturgicznej fabuły do dominacji postaci, a w konsekwencji od obrazu świata zewnętrznego do zsubiektywizowanego obrazu umysłu. E. Fuchs, Śmierć postaci scenicznej, tłum. P. Konic, „Dialog” 1989, nr 11-12. Transformacjom postaci scenicznej we współczesnej dramaturgii poświęcone zostało także opracowanie Grzegorza Sinki Postać sceniczna i jej przemiany $w$ teatrze $X X$ wieku (Wrocław 1988).

${ }^{14}$ Stownik dramatu nowoczesnego i najnowszego, red. J.-P. Sarrazac, thum. M. Borowski, M. Sugiera, Kraków 2007, s. 128.

${ }^{15}$ D. Ratajczakowa, Dramat $z$ dramatem, w: eadem, $W$ krysztale $i$ w ptomieniu. Studia i szkice o dramacie i teatrze, t. 1, Wrocław 2006, s. 101. 
Stanowiłby on rodzaj transmedialnej matrycy dramatyczno-teatralnej jako głębokiej struktury tekstu:

- dominacja ruchomego obrazu,

- fragmentaryzacja narracji związana z degradacją mówiącej postaci,

- heterogeniczność stylu artystycznego,

- brak ciągłości,

- pluralizm,

- wielokodowość,

- aliterackość,

- subwersyjność,

- deformacja,

- pojmowanie zdarzenia teatralnego jako procesu work in progress,

- hipernaturalizm,

- neoekspresjonizm ${ }^{16}$.

Propozycję Lehmanna można uznać za próbę nowej systematyki dramatyczno-teatralnej, zastępującej rezerwuar form gatunkowych wiązką nieprzystawalnych, formotwórczych, dowolnie montowanych modułów. Jako dynamizmy konstytuujące „subwersywną" gramatykę tekstu wyprowadzone zostają z innorodnych, nieprzekładalnych systemów. Tworzą repertuary niezależnych, uniwersalnych chwytów jako niespecyficznych operacji na tekście. Stanowiąc wieloperspektywiczną, transmedialną konstelację różnokategorialnych elementów, nie mieszczą się już zatem w proponowanych przez Balcerzana szeregach genologicznych, gwarantowanych formalnym porządkiem przyległości lub podobieństwa. Tworzą one bowiem nie tylko bogatą paletę zjawisk intertekstualnych i transtekstualnych, ale także transsystemowych, przemieszczając „neodramat” nie tylko poza przestrzeń literatury pięknej, ale często i poza gatunki mowy. Niewystarczająca zatem w lekturze najnowszego dramatu okazuje się formuła „gatunków zmąconych” czy „skotłowania form” proponowana przez Clifforda Geertza ${ }^{17}$. Być może, per analogiam do konceptu ,zjawiska eseju” Romy Sendyki ${ }^{18}$, stanowiącego antidotum na jego „niegatunkowy” bądź wręcz „antygatunkowy” charakter, zamiast o nowym dramacie jako kategorii genologicznej moglibyśmy zatem mówić jedynie o aporetycznym, wymykającym się ostrym klasyfikacjom, ergo niekategorialnym, „zjawisku dramatu”. W związku z postmodernistycznym kryzysem gatunków literackich oraz aktualną nieużytecznością tradycyjnych badań nad immanentną poetyką tekstu, warto, za Grzegorzem Grochowskim,

${ }^{16}$ H.-T. Lehmann, op. cit., s. 22.

${ }^{17}$ C. Geertz, O gatunkach zmaconych (Nowe konfiguracje myśli społecznej), tłum. Z. Lapiński, w: Postmodernizm. Antologia przekładów, red. R. Nycz, Warszawa 1997. s. 88 .

${ }^{18}$ R. Sendyka, Nowoczesny esej. Studium historycznej świadomości gatunku, Kraków 2006, 
zastanowić się nad „ewentualną przydatnością pojęć »perspektywy«, »oglądu«, "punktu widzenia « jako narzędzi stosowanych ostatnio coraz częściej do opisywania złożonych konwencji gatunkowych" ${ }^{19}$. Uwzględniających kognitywistyczne, wprowadzające więc w miejsce ostrych definicji figurę metafory, strategie rozpoznań. Włączających w obszar, teraz arbitralnej, refleksji badacza zagadnienie „naturalnej kategoryzacji” zjawisk, „radialnej struktury” znaczenia czy rozciągliwości „zbiorów rozmytych”" ${ }^{20}$. Prowadzących od konstruowania intersubiektywnej systematyki form do świadomości gatunku kształtowanej z wybranej perspektywy lektury.

Jak się wydaje, szczególnie funkcjonalną odpowiedzią na rozpoznane zjawiska „wyczerpania” form gatunkowych w dyskursie teoretycznoliterackim, dotyczącym nade wszystko „zdradzającego" sztukę słowa trzeciego rodzaju, okazują się narzędzia poetyki kulturowej. Co istotne - w znacznym stopniu o teatralnej przecież proweniencji. Zaproponowane przez Stephena Greenblatta, m.in. w jego rozważaniach poświęconych scenie elżbietańskiej i dramatom Szekspira, ufundowały nowy rodzaj refleksji o literaturze osadzony w tak ważnych dla sztuki teatru kontekstach społeczno-politycznych, odwołujących się także do rozpoznań z zakresu antropologii kultury czy teorii komunikacji. Kulturowa optyka badań nad dramatem i teatrem jako najbardziej społeczną ze sztuk, pomieszczoną w zbiorowym „tu i teraz”, stanowi użyteczne narzędzie opisu nie tylko procesów historycznoteatralnych, ale także szeroko pojmowanych praktyk kulturowych i społecznych. Wskazująca na znaczenie studiów kulturowych jako remedium na poststrukturalistyczny kryzys genologii Roma Sendyka podkreśla, iż:

„Gatunek” jest sposobem opisu, narzędziem służącym identyfikacji różnych rodzajów tekstów, nie zaś normatywizacji i ocenie dzieł literackich. [...] Granice między gatunkami stały się znowu interesujące, lecz nie jako miejsca rygorystycznego rozdzielenia - lecz jako przestrzeń dynamicznych zderzeń, łączenia, rozmycia, krzyżowania się różnych właściwości²1

Nowe zjawiska formatotwórcze ujawniają powoli rozpoznawalne, powracające w poetyce dramatu, jednak pochodzące $z$ różnych systemów, chwyty ${ }^{22}$. Czy zatem ich „konstelacja” pozwala już na wyabstrahowanie kolejnej, podlegającej konwencjonalizacji rodzajowej taksonomii?

${ }^{19}$ G. Grochowski, Pamięć gatunków. Ponowoczesne dylematy atrybucji gatunkowej, Warszawa 2018, s. 249.

${ }^{20}$ Ibidem.

${ }^{21} \mathrm{R}$. Sendyka, $W$ stronę kulturowej teorii gatunku, w: Kulturowa teoria literatury. Główne pojęcia i problemy, red. M. P. Markowski, R. Nycz, Kraków 2006, s. 277.

${ }^{22}$ Problem ewolucji dwudziestowiecznych form dramatycznych, destruujących klasyczne wyznaczniki kompozycyjne rodzaju, podejmowała m.in. Anna Krajewska (Dramat $i$ teatr absurdu w Polsce, Poznań 1996; Dramat wspótczesny. Teoria i interpretacja, Poznań 2005). Przedmiotem 


\section{Poetyka hybrydowa}

Poetyka hybrydowa okazuje się kategorią nadrzędną, ogarniającą wiele zjawisk dyrektywą „tekstotwórczą”. Wspólną dla jej zróżnicowanych manifestacji strategią artystyczną jest demontaż tradycyjnych norm gatunkowych, miksowanie wielorakich form pisma (także nieliterackich) i łączenie ich często w całości kompozycyjne z tekstami o pozasłownym rodowodzie. Ów zabieg implementowania $\mathrm{w}$ tekst dramatyczny obcych elementów pochodzących z szerokiego, pozaliterackiego uniwersum praktyk kulturowych i społecznych stanowi zjawisko poniekąd komplementarne wobec będących przedmiotem namysłu Grzegorza Grochowskiego „hybryd tekstowych” ${ }^{23}$, traktowanych przezeń jako przenikanie się tekstów literackich $\mathrm{z}$ nieliterackimi. Polegające $\mathrm{z}$ kolei nade wszystko na odwrotnym przenoszeniu „cech literackości” w obręb dyskursów nieliterackich i to zamkniętych jednak wyłącznie w medium słowa. Co istotne, w ujęciu Grochowskiego owe hybrydyczne formy mają charakter jednorazowy, nieprowadzący zatem do wykształcenia się nowych wzorców genologicznych. W najnowszej dramaturgii możemy jednak obserwować już proces konstytuowania się „hybrydowych” zjawisk poetologicznych krzyżujących różne właściwości gatunków i właściwości różnych tekstów, powracających ze szczególną częstotliwością, wyznaczających zatem nową, trwałą estetykę rodzaju.

\section{Posttradycja}

Zabieg reinterpretacji tekstów zaczerpniętych z powszechnego kanonu literackiego jest zjawiskiem znanym od dawna. Dramaturgia lat ostatnich, podejmując szczególnie często intertekstualne gry z klasyką, czyni to jednak z reguły w sposób zaprzeczający utrwalonej tradycji jej stylizacji. Zapoczątkowana w latach sześćdziesiątych XX w. przez Heinera Müllera przeróbkami tekstów dawnych z najważniejszym wśród nich utworem HamletMaszyna - moda na przepisywanie dramatów przynosi ze sobą wiele rekontekstualizujących transformacji

refleksji Krajewskiej pozostaje jednak nade wszystko polska dramaturgia absurdu. Diagnozowane w niej nowe zjawiska formatotwórcze, awangardowe w momencie powstawania omawianej twórczości, zamykają je zatem - w oczywisty sposób - w obszarze konsekwentnej literackości. Mieszczą się więc one w paradygmacie definiowanej przez Balcerzana genologii monomedialnej i w znacznym stopniu w spektrum zagadnień dyskutowanych przez Martina Esslina. Dramaturgii powstałej już wyłącznie po 1989 r. poświęcone zostały natomiast prace Marty Karasińskiej, analizującej strategie kompozycyjne „nowego dramatu” w perspektywie poetyki kulturowej - głównie geopoetyki (Ja, Miasto. Szkice o (nie tylko) polskiej dramaturgii lat ostatnich, Poznań 2011) i Beaty Popczyk-Szczęsnej (Dramaturgia polska po 1989 roku, Katowice 2013). Obie autorki dyskutują m.in. zagadnienie estetyki postdramatycznej, intertekstualnej gry z tradycją literacką, teatru głosu czy języka, hybrydycznych scenariuszy teatralnych wykraczających poza terytorium słowa, ze szczególnie częstym odwołaniem do kategorii popkultury, tekstu miasta, gatunków telewizyjnych i publicystyki.

${ }^{23}$ G. Grochowski, Tekstowe hybrydy, Wrocław 2000. 
dzieł Szekspira (Król Lear Rodriga Garcìi, Szaleństwo Troilusa i teatr Kresydy Wernera Schwaba), Sofoklesa (Antygona w Nowym Jorku Janusza Głowackiego, Antygona Kreona Mira Gavrana), Racine'a (Fedra Sarah Kane, Ifigenia. Nowa tragedia Pawła Demirskiego i Michała Zadary), Goethego (transrodzajowa przeróbka Werter w Nowym Jorku Tima Staffela). Zyskujące dużą autonomię utwory nie są już jednak, jak teksty Müllera, tylko próbą „uaktualnienia” klasyki, uwspółcześniającego zderzenia jej z nowym czasem, sztuką najnowszą i jego odbiorcą. Okazują się nierzadko gniewną odpowiedzią na kryzys i wyczerpanie literatury, obrazoburczym gwałtem na pierwowzorze, trywializującym jego przekaz aksjologiczny, przesłanie filozoficzne i negującym wymiar estetyczny uznanego arcydzieła. Często już nie aktualizują, a unieważniają kulturowe dziedzictwo. Degradują i demontują jego przeniesionego we współczesność bohatera, rozrywają fabułę, dewaluują słowo i wulgaryzują styl, wprowadzają elementy popkultury i sztuki mediów cyfrowych. Wędrują po motywach, strzępach tradycji - spektakularnie deprecjonując historię i dewastując historycznie utrwalone cezury. Idący jeszcze dalej w destruowaniu pierwowzoru zabieg recyklingu, związany $\mathrm{z}$ nurtem junk art, całkowicie już demontuje oryginał i dekontekstualizuje wyjęte $z$ niego elementy, sprowadzając motywy zapożyczone z tekstów wysokiej kultury do roli uzdatnianych odpadów. Składanych na powrót $\mathrm{w}$ całkowicie nową jakość zmontowaną z niezależnych, nieprzystających do siebie, ledwie przywołanych, pochodzących z odzysku tekstualnych okruchów - strzępów fabuł, postaci, cytatów, stylistyk. Pozostająca w obszarze „sztuki ekologicznej” poetyka teatralnego recyklingu na ogół w zamierzeniu nobilituje jednak przywracane obiegowi kulturowemu tekstowe „surowce wtórne” wykorzystywane teraz jako pełnowartościowe tworzywo kolejnych, autonomicznych dzieł. Adresowana do młodego widza sztuka Śnieży Roberta Jarosza stanowi dalekie echo Królowej Śniegu. Para bohaterów, Złota i Srebrny, ledwie aluzyjne przywołuje losy Gerdy, Kaja oraz samego Andersena. Metaforycznym zaczynem akcji, rozpadającej się na nieprzystawalne segmenty, staje się, jak w klasycznej wersji baśni, rozbite na kawałki lustro, odbijające pokawałkowaną tradycję. Autorem często sięgającym do poetyki recyklingu jest Mateusz Pakuła. Jego nawiązujący tytułem do strategii pisarskich Müllera KonradMaszyna miesza konwencje, kryptocytaty z polskiej klasyki literackiej i slogany reklamowe, $\mathrm{Na}$ końcu łańcucha miksuje zapożyczenia z Szekspira, Müllera, Wernera Schwaba i Bernarda-Marie Koltèsa... Przepisywanie dramatu i recykling jako techniki nowego dramatopisania to odpowiedź na postmodernistyczną estetykę czy szerzej - kulturę remiksu, opartą na dynamice odczytu i zapisu, dekontekstualizacji i rekontekstualizacji, wymianie elementów budującej pomost nie tylko między oryginałem i tekstem „pasożytniczym”, ale otwierającym tekst literacki na transmedialne fuzje. 


\section{Dramat głosu}

Dramat głosu, wyzuty z obrazu, stanowi kolejną odsłonę rozpadu i eliminacji podmiotowego bohatera. Oderwany od postaci, odcieleśniony głos staje się wyłącznie nieredukowalnym medium mowy, teraz usamodzielnionego, często nieskładnego potoku słów ${ }^{24}$. Sfragmentaryzowany, afabularny tekst bywa kolażem strzępów telewizyjnych newsów, debat publicznych i spotów reklamowych, biznesowego żargonu i beznamiętną rejestracją wielkomiejskiej heteroglosji. Jest prezentystycznym, niekończącym się komunikacyjnym szumem. Zapisem „zasłyszanej” społecznej fonosfery i „podsłuchanego” strumienia zdezintegrowanej świadomości. Pozbawieni imion własnych, odarci z podmiotowości bohaterowie Trylogii z Prateru René Pollescha przepuszczają przez siebie automatycznie bezforemne potoki społeczno-politycznych debat. Przemieszane, anonimowe głosy w Jeffie Koonsie Goetza wyłaniają z kakofonii monologów fragmenty nieukazanego na scenie miejskiego pejzażu. Pod lodem i Electronic City Falka Richtera rejestrują niezborne myśli zaplątanego w komunikacyjnym kłączu człowieka. Niekoherentne „głosowisko" transmituje amorficzny zgiełk mowy, odklejone od indywiduum cudze teksty i heterogeniczne dyskursy. Zabieg dezintegracji bohatera rozpadającego się na niespójne akty językowe wykorzystywany zostaje nawet $\mathrm{w}$ dramaturgii dla dzieci. Podejmujący temat aborcji, adresowany do najmłodszych tekst Tak jest Maliny Prześlugi „dopuszcza do głosu” nieukonstytuowane jeszcze w zindywidualizowane ,ja" narządy rozwijającego się płodu.

\section{Transgraniczność}

Dramat dokumentalny stanowi wyrazistą, utrwaloną od kilkudziesięciu lat formułę dramatopisania, oscylującą między literaturą piękną, gatunkami publicystycznymi i „ruchomym obrazem”, która z impetem przypomniała o sobie w latach dziewięćdziesiątych XX w. Jej aktem założycielskim był w latach dwudziestych teatr epicki, łączący w hybrydycznych inscenizacjach i wychodzących poza gatunek słowa faktomontażach Erwina Piscatora dokument i sceniczne techniki medialne (fotografie, film). Za twórcę dramatu dokumentalnego uznaje się jednak powszechnie Petera Weissa, autora opartych na faktach utworów scenicznych, ale nade wszystko programowego artykułu Notatki o teatrze faktu z 1968 r. ${ }^{25}$ Dotyczy on nie tylko zadań społeczno-politycznych dramatu dokumentalnego, ale także jego estetyki. Za najważniejsze wyznaczniki gatunkowe

${ }^{24} \mathrm{Na}$ postępującą degradację postaci i dialogu w nowej dramaturgii niemieckiej (Elfriede Jelinek, Werner Szwab, Oliver Bukowski, Rainald Goetz), prowadzącą do zdominowania materii dramatu przez „uwolnioną oralność”, narzucającą konieczność rewizji dotychczasowych definicji trzeciego rodzaju, zwracała uwagę Gerda Poschmann. Eadem, Der nicht mehr dramatische Theatertext. Aktuelle Bühnenstücke und ihre dramaturgische Analyse, Tübingen 1997.

${ }^{25} \mathrm{P}$. Weiss, Notatki o teatrze faktu, tłum. M. Leyko, w: O dramacie. Od Sartre'a do Mrożka. Poetyki, manifesty, komentarze, red. E. Udalska, Warszawa 1997. 
teatru-raportu uważa Weiss włączanie w korpus tekstu autentycznych dokumentów (statystyk, bilansów bankowych, reportaży prasowych, a także materiałów fotograficznych i filmowych). Jego poetykę, bliską teorii epickiego teatru Brechta i Piscatora, charakteryzuje skłonność do rozluźniania i rozrywania struktury tekstu oraz kolażowego łączenia innorodnych chwytów artystycznych i fuzji mediów. Nawiązaniem do tradycji stał się w latach ostatnich teatr verbatim, spopularyzowany przede wszystkim przez sceny brytyjskie i rosyjski Teatr.Doc. $\mathrm{W}$ repertuarze zespołów angielskich pojawiły się dramaty związane z polityką społeczną Margaret Thatcher, poświęcone wojnie o Falklandy, prywatyzacji kolei. Rosyjska docudrama podjęła tematy kolonii karnych kobiet, mniejszości seksualnych, emigrantów z republik azjatyckich. Popularna i w Polsce metoda verbatim (Teatr Polski w Bydgoszczy, Szybki Tramwaj Miejski w Gdańsku, Teatr Ósmego Dnia, liczne projekty kuratorskie) sytuuje powstający tekst na granicy literatury i gatunków publicystycznych. Wykorzystuje nie tylko gotowe już dokumenty, ale też przeprowadzone specjalnie na użytek spektaklu nagrania, wywiady, reportaże, rejestracje filmowe łączone metodą cut-up $\mathrm{w}$ formę niejednorodnego, parapublicystycznego scenariusza.

Homologia struktur jako podstawa kompozycyjna jest operacją transkategorialną opierającą się na translacji systemów nie tylko nieliterackich, ale i niejęzykowych na tekst dramatyczny ${ }^{26}$. Oparta na podobieństwie morfologicznym innorodnych układów stanowi dyrektywę przekładową, obierająca jako podstawę konstrukcyjną utworu scenicznego plan miasta, architekturę wieżowca czy grę komputerową. Sprowadzone do abstrakcyjnego modelu generują układy zdarzeń i ogarniającą je czasoprzestrzeń. Budowane często z niezależnych modułów teksty otwierają się na różnorodne porządki pozwalające potencjalnie na tasowanie i przemieszczanie samodzielnych, a niekiedy opcjonalnych, jednostek fabularnych. Zapożyczany jako spacjalna matryca tekstu układ składającego się z klatek mieszkań wieżowca, zgodnie z chaotycznym ruchem windy, pozwala przedstawiać historie lokatorów z poszczególnych pięter zgodnie z losowym porządkiem jej tras (Arabska noc Rolanda Schimmelphenniga). „Flanerujący” po mieście bez celu bohaterowie Puzzli Szymona Wróblewskiego ułożą jego obraz z segmentów-klocków w zgodzie z przypadkowym rozkładem swojej wędrówki. Bohater Electronic City Falka Richtera zagubi się w hipertekstualnej informatycznej sieci bez początku i końca. Histerikon Ingrid Lausund połączy prezentowane miniepizody, respektując układy półek wielkomiejskiego supermarketu.

${ }^{26}$ Proponowana przeze mnie kategoria „homologii struktur” przywodzi na myśl znany koncept „cytatu struktury” wprowadzony do dyskursu teoretycznego przez Danutę Danek, ograniczony jednak do przejmowania w korpus dzieła literackiego struktur jedynie poetyk artystycznych, innych niż występujące w tekście macierzystym, w tym także formatów gatunkowych. Eadem, O polemice literackiej w powieści, Warszawa 1972. 
Teksty dramatyczne, czy niekiedy bardziej scenariusze teatralne, umieszczane na pograniczach mediów, wielokrotnie sprawiają trudność z zakwalifikowaniem ich do określonej precyzyjnie domeny komunikacyjnej. Scalają tekst literacki z tekstami innorodnych mediów, traktując je bądź jako upodrzędniony jeszcze implant (immersja), bądź jako pełnoprawnego już partnera (konwergencja) ${ }^{27}$. Gdy proponują nowe gatunki, sytuują je w obszarach międzymedialnych (sitcom, reality show, formy publicystyczne, technoperformanse etc.). Utrwalonym od lat chwytem implantowania przez dramat obcego medium jest wprowadzanie na scenę rozszerzającego świat przedstawiony obrazu z monitora, anektowanie przez tekst literacki technik i poetyk sztuk wizualnych - m.in. montażu. Spełniające już kryteria zabiegu konwergencji Factory Igora Bauersimy, Reality show(s). Kabaret o rzeczach strasznych Przemysława Pilarskiego, Sitcom Krzysztofa Bizia opierają się na strukturach gatunkowych popularnych widowisk telewizyjnych. Hybrydowa kompozycja wiąże nierozerwalnie słowo $\mathrm{z}$ wideo i obrazem cyfrowym. Łączy różne porządki czasoprzestrzenne, realną rzeczywistość i świat wirtualny. Jest intertekstualnym i wielotworzywowym patchworkiem. Dramat ewoluuje ku technosztuce. Sprowadza postać literacką do anonimowego głosu, wymienia na wizerunek elektroniczny i cyfrowego awatara. Eliminuje ze sceny zewnętrzną wobec bohatera fizyczną przestrzeń, przeniesioną przez ekspresjonizm do jego jaźni, teraz zamieniając ją na abstrakcyjną przestrzeń oswobodzonego języka i hybrydową, atemporalną przestrzeń wirtualną. Autorskie scenariusze teatralne Pawła Passiniego, realizowane w ramach internetowego neTTheatre, sięgają do nowych technologii przetwarzania obrazu i dźwięku. Wprowadzają na wirtualną scenę interaktywnego tancerza, cyfrową wizualizację ludzkiego głosu, wykorzystują gest aktora w roli edytora tekstu. Zachęcają odbiorcę do zdalnego, interaktywnego współtworzenia spektaklu. Berliński teatr Rimini Protokoll swój scenariusz Termin przydatności opiera na regułach gier komputerowych, zapraszając widzów do sterowania ukazywanym na ekranie życiem małej społeczności. Interaktywny cyberdramat wywraca na nice klasyczną definicję teatru jako „sztuki żywej”, dematerializuje aktora, zastępuje człowieka postczłowiekiem.

Unicestwianie cezur międzygatunkowych, międzymedialnych czy międzysystemowych na poziomie głębokiej struktury nowego dramatu dokonuje się na dwa przeciwstawne sposoby. Strategia konfrontowania zderza heterogeniczne, obce paradygmaty tekstualne, akcentując ich nieprzystawalność. Opiera się na uniwersalnych operacjach na systemach (także literackich), zarządzających porządkiem składających się nań segmentów. Wykorzystuje techniki montażu,

${ }^{27}$ Terminy stosuję za Henrym Jenkinsem. Idem, Kultura konwergencji: zderzenie starych i nowych mediów, tłum. M. Bernatowicz, M. Filiciak, Warszawa 2007. 
kolażu, puzzli, patchworku, cut-up, budując tekstowe hybrydy. Strategia scalania innorodnych elementów rozmywa wyodrębniające je różnice bądź, idąc dalej, spaja ze sobą w jedno nakładające się na siebie homologiczne modele (tekst literacki z grą komputerową, sitcomem, planem miasta, gatunkiem publicystycznym). Strategia pierwsza mieściłaby się w przestrzeni genologii intermedialnej, druga spełniałaby już kryterium transmedialności. Współczesne dramaty czy scenariusze teatralne, zatopione $\mathrm{w}$ kulturze informatycznych sieci, jawiące się jako poddany dominacji sztuki masowej polimorficzny neosystem, wyraziście zatem akcentują swój metakomunikacyjny wymiar. Nowe formy kategorialne postdramatu coraz częściej także rezygnują z materii literackiej, przemieszczając się z obrębu literatury w obszar szeroko definiowanych mediów i praktyk społecznych, przekraczając tym samym jedną z fundamentalnych dla teorii sztuki cezur. Dramat konsekwentnie opuszcza terytorium słowa, pozostawiając po sobie jak w sztuce $W$ środku stońca gromadzi się popiót Artura Pałygi - jedynie niedodrukowane kartki.

\section{Bibliografia}

Balbus, Stanisław, „Zagłada gatunków”, „Teksty Drugie” 1999, nr 6.

Balcerzan, Edward, W stronę genologii multimedialnej, „Teksty Drugie” 1999, nr 6.

Danek, Danuta, O polemice literackiej w powieści, Warszawa 1972.

Esslin, Martin, The Theatre of the Absurd, Garden City 1961.

Fuchs, Elinor, Śmierć postaci scenicznej, thum. P. Konic, „Dialog” 1989, nr 11-12.

Geertz, Clifford, O gatunkach zmaconych (Nowe konfiguracje myśli spotecznej), thum. Z. Łapiński, w: Postmodernizm. Antologia przektadów, red. R. Nycz, Warszawa 1997.

Greenblatt, Stephen, Poetyka kulturowa: pisma wybrane, red. i wstęp K. Kujawińska-Courtney, Kraków 2006.

Grochowski, Grzegorz, Pamięć gatunków. Ponowoczesne dylematy atrybucji gatunkowej, Warszawa 2018.

Grochowski, Grzegorz, Tekstowe hybrydy, Wrocław 2000.

Jenkins, Henry, Kultura konwergencji: zderzenie starych i nowych mediów, thum. M. Bernatowicz, M. Filiciak, Warszawa 2007.

Karasińska, Marta, Ja, Miasto. Szkice o (nie tylko) polskiej dramaturgii lat ostatnich, Poznań 2011.

Krajewska, Anna, Dramat i teatr absurdu w Polsce, Poznań 1996.

Krajewska, Anna, Dramat wspótczesny. Teoria i interpretacja, Poznań 2005.

Lehmann, Hans-Thies, Teatr postdramatyczny, tłum. D. Sajewska, M. Sugiera, Kraków 2004.

Popczyk-Szczęsna, Beata, Dramaturgia polska po 1989 roku, Katowice 2013.

Poschmann, Gerda, Der nicht mehr dramatische Theatertext. Aktuelle Bühnenstücke und ihre dramaturgische Analyse, Tübingen 1997. 
Ratajczakowa, Dobrochna, Dramat $z$ dramatem, w: eadem, $W$ krysztale $i$ w ptomieniu. Studia i szkice o dramacie i teatrze, t. 1, Wrocław 2006.

Sendyka, Roma, Nowoczesny esej. Studium historycznej świadomości gatunku, Kraków 2006.

Sendyka, Roma, W stronę kulturowej teorii gatunku, w: Kulturowa teoria literatury. Gtówne pojęcia i problemy, red. M. P. Markowski, R. Nycz, Kraków 2006.

Sinko, Grzegorz, Postać sceniczna i jej przemiany w teatrze XX wieku, Wrocław 1988.

Słownik dramatu nowoczesnego i najnowszego, red. J.-P. Sarrazac, tłum. M. Borowski, M. Sugiera, Kraków 2007.

Szondi, Peter, Teoria nowoczesnego dramatu 1890-1950, tłum. E. Misiołek, Warszawa 1976.

Weiss, Peter, Notatki o teatrze faktu, tłum. M. Leyko, w: O dramacie. Od Sartre’a do Mrożka. Poetyki, manifesty, komentarze, red. E. Udalska, Warszawa 1997.

Wysłouch, Seweryna, Nowa genologia - rewizje i interpretacje, w: Polska genologia. Gatunek w literaturze wspótczesnej, red. R. Cudak, Warszawa 2009.

MARTA KARASIŃSKA - prof. zw. dr hab., literaturoznawca i teatrolog. Kierownik Pracowni Opery i Widowisk w Instytucie Filologii Polskiej UAM. Zajmuje się teorią teatru i dramatu, dramaturgią współczesną, teatrem i dramatem dla dzieci. 